Kalpa Publications in Civil Engineering
Volume 1, 2017, Pages 87-92
$\begin{gathered}\text { ICRISET2017. International Conference on Re- } \\ \text { search and Innovations in Science, Engineering } \\ \text { \&Technology. Selected papers in Civil Engineering }\end{gathered}$

\title{
Effects Of Vertical Geometric And Mass Irregularities In Structure
}

\author{
Kevin Shah ${ }^{1}$ and Prutha Vyas ${ }^{2}$ \\ ${ }^{1}$ Under graduate Student, ${ }^{2}$ Assistant Professor \\ Civil Engineering Department School of Engineering and Technology, \\ Navrachana University, Vadodara, India \\ shahkevin59@gmail.com, pruthav@nuv.ac.in
}

\begin{abstract}
Earthquake design plays major role in designing of any structure. The base shear is developed during an earthquake in a structure. The base shear is calculated by using the codes IS 1893:2002 (Part-1). The study includes the calculations of storey shear, storey drift and storey displacement of G+14 building which is situated in zone- 5 with different irregularities. Irregularities are crucial in studying the seismic behavior of building. The irregularities considered are mass irregularity and vertical geometric irregularity. The mass irregularity has first floor without masonry wall and rest of floor with infill masonry wall i.e. soft storey and vertical geometric irregularity has uneven geometry in vertical position \& shape of building. In very severe earthquake zone, structure fail due to high lateral loads in this project lateral loads are considered in both direction (EQX \& EQY). The modelling and calculations of building are done using ETABS.
\end{abstract}

Keywords: Base shear, Story Drift, Story Displacement, vertical geometric irregularity, Mass irregularity

\section{Introduction}

Earthquake is most disastrous natural calamity. It is impossible to design earthquake proof structure so engineers try to design earthquake resistant structure. It is important to determine lateral forces for analyses of earthquake resistant structure. Seismic analysis is carried out with using linear static analysis method as per IS:1893-2002 (I).

The failure or weakness of structure starts from discontinuity or irregularity. This discontinuity may be in teams of mass, geometry and stiffness of building or structure. One of the major factors is Vertical irregularities for failures of structures. Height-wise changes in stiffness and mass render the dynamic characteristics of these buildings different from the 'regular' building. 
There are two types of irregularities- Plan Irregularities, Vertical Irregularities.

Vertical Irregularities are mainly of five types:

\section{Stiffness Irregularity -}

a. Soft Story- A soft story is one in which the lateral stiffness is less than 70 per-cent of the story above or less than 80 per-cent of the average lateral stiffness of the three stories above.

b. Extreme Soft Story- It is one in which the lateral stiffness is less than 60 per-cent of that in the story above or less than 70 per-cent of the average stiffness of the three Story's above.

2. Mass Irregularity- When the weight of any story is more than 200 percent of the adjacent story, then it considered as mass irregularity.
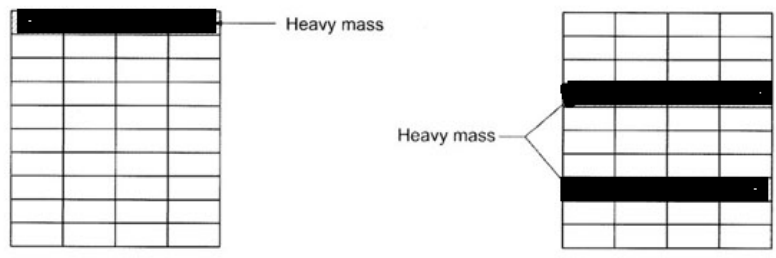

Figure 1: Mass Irregularity
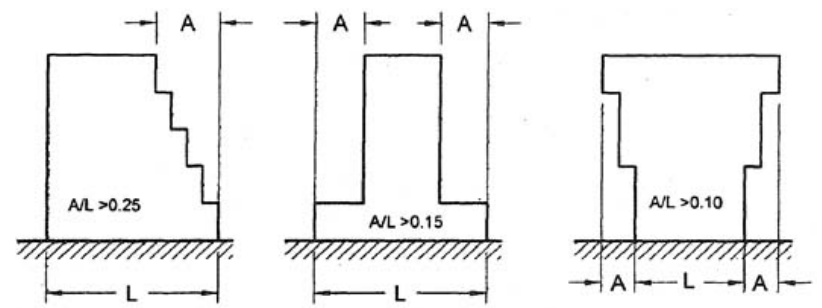

Fig. 2: Vertical geometric irregularity

3. Vertical Geometric Irregularity- A structure is considered to be Vertical geometric irregular when the horizontal dimension of the lateral force resisting system in any story is more than 150 percent of that in its adjacent story.

4. In-Plane Discontinuity in Vertical Elements Resisting Lateral Force-An in-plane offset of the lateral force resisting elements greater than the length of those elements.

5. Discontinuity in Capacity-Weak Story-A weak story is one in which the story lateral strength is less than 80 per-cent of that in the story above.

\section{Literature Review}

S Monish \& S Karuna [3] studied the effect of vertical irregularity i.e. vertical geometric irregularity and stiffness irregularity due to sloping ground in high rise buildings for different 7 models of RC building under severe seismic zone. And compare parameters i.e. displacement, Drift and base shear. 
Abul Hasnat \& M Rahim [4] studied response of a 15- storeyed frame to lateral loads is for stiffness and vertical irregularities. The proportional distribution of lateral forces evolved through seismic action and wind load also in each storey level due to changes in stiffness of frame on irregular

frame is analyzed. Also compare parameters i.e. story drift and displacement $\mathrm{n}$ both $\mathrm{X}$ and $\mathrm{Y}$ direction.

\section{Seismic Analysis}

Base shear is the maximum shear force that will occur due to seismic ground motion at the base of the structure. The calculations of Earthquake base shear for building as per IS:1893-2002. The base shear, or earthquake force, is given by the symbol "VB". The weight of the building is given as the symbol "W". In general, the base shear formula looks like this

$V_{B}=A h \times W$

$V_{\mathbf{B}}=$ Base Shear, $\mathrm{Ah}=$ Horizontal Seismic Coefficient

$\mathrm{W}=$ Total Weight of Structure

$$
\mathrm{A}_{\mathrm{h}}=\frac{I}{R} \times \frac{Z}{2} \times \frac{S a}{G}
$$

$\mathrm{Z}=$ Zone Factor, $\mathrm{I}=$ Importance Factor, $\mathrm{R}=$ Response Reduction Factor

The storey drift in any storey due to the minimum specified design lateral force, with partial load factor of 1.0, shall not exceed 0.004 times the storey height. There shall be no drift limit for single storey building which has been designed to accommodate storey drift.

\section{Parametric Studies}

Dimensions of building are plan size $24 \times 15 \mathrm{~m} . \mathrm{G}+14$ story RC building having story height $3.2 \mathrm{~m}$ each. Total story height is $48 \mathrm{~m}$. Analyses of building for three cases are carried out. Case- 1 is for symmetric RC building with infill masonry walls. Case-2 is for mass irregularity building and case 3 is for vertical irregularity i.e. stiffness irregularity. Analysis and design of building is carried by ETABS.

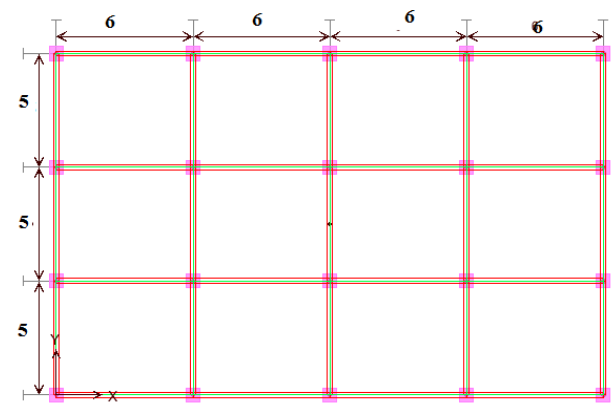

Figure 3: Plan of building

\section{Modeling in ETABS}

Beams and Columns are modelled as frame elements. Slab and masonry walls modelled as plate element. Application of Loads:

Dead load of building will be taken care of ETABS software itself. Live load is taken $3 \mathrm{kN} / \mathrm{m}^{2}$. Seismic loads are defined in ETABS for zone V. Importance factor (I) is 1.5, Response Reduction factor $(\mathrm{R})$ is 5 . And considering soil type II. 


\begin{tabular}{|c|c|}
\hline Size of Building plan & $24 \times 15 \mathrm{~m}$ \\
\hline Height of Building & $48 \mathrm{~m}$ \\
\hline Story Height & $3.2 \mathrm{~m}$ \\
\hline Grade of Concrete & $\mathrm{M} 25$ \\
\hline Grade of steel & Fe415 \\
\hline $\begin{array}{c}\text { Modulus Elasticity of } \\
\text { masonry }\end{array}$ & $3500 \mathrm{~N} / \mathrm{mm}^{2}$ \\
\hline
\end{tabular}

Table 1 Basic input parameters

\section{Results And Comparison Of Graphs}

Three parameters i.e. story displacement, story shear and Drift are compared by graphs for both direction $\mathrm{X}$ and $\mathrm{Y}$.
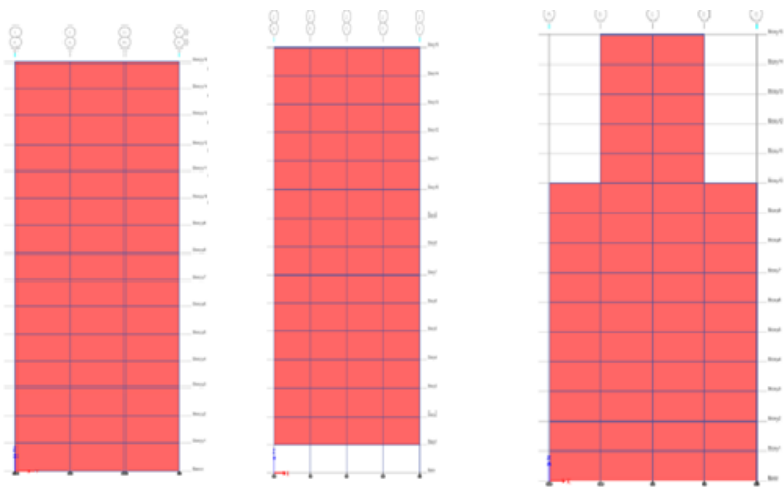

Figure 4: Elevation of buildings

\begin{tabular}{|c|c|c|c|}
\hline & CASE 1 & CASE 2 & CASE 3 \\
\hline $\begin{array}{c}\text { Beam Size } \\
(\mathrm{mm})\end{array}$ & $300 \times 450$ & $250 \times 400$ & $250 \times 400$ \\
\hline $\begin{array}{c}\text { Column } \\
\text { Size (mm) }\end{array}$ & $450 \times 450$ & $600 \times 600$ & $600 \times 600$ \\
\hline $\begin{array}{c}\text { Thickness } \\
\text { of Slab } \\
(\mathrm{mm})\end{array}$ & 150 & 150 & 150 \\
\hline $\begin{array}{c}\text { Thickness } \\
\text { of } \\
\text { masonry } \\
\text { wall (mm) }\end{array}$ & 250 & 250 & 250 \\
\hline
\end{tabular}




\section{Conclusion}

- $\quad$ Base shear is more for case 1 than other two cases because of it has symmetric infill with masonry walls on all levels.

- Abrupt change in story drift in case 2 at story level 1, due to sudden change of stiffness.

- Story drift for case 3 is having uniform pattern from ground to $10^{\text {th }}$ story level and 12 to 15 story level. But there is fast variation in 10 to 12 due to sudden vertical irregularity.

- Top story displacement is maximum for vertically irregular of structure and minimum for symmetric infill wall structure.

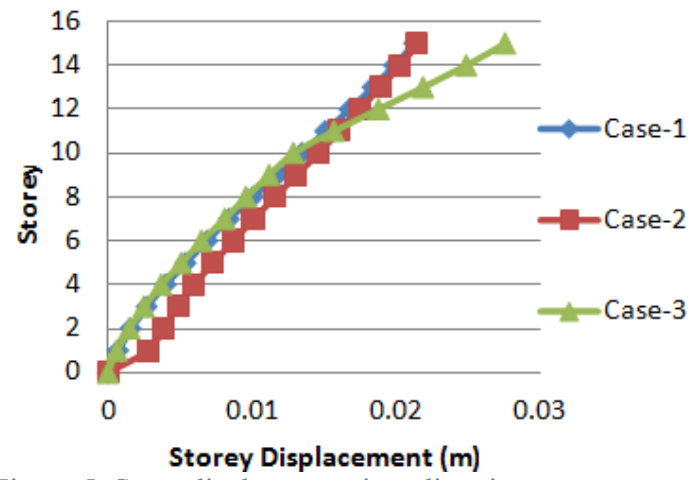

Figure 5: Story displacement in $\mathrm{x}$ direction

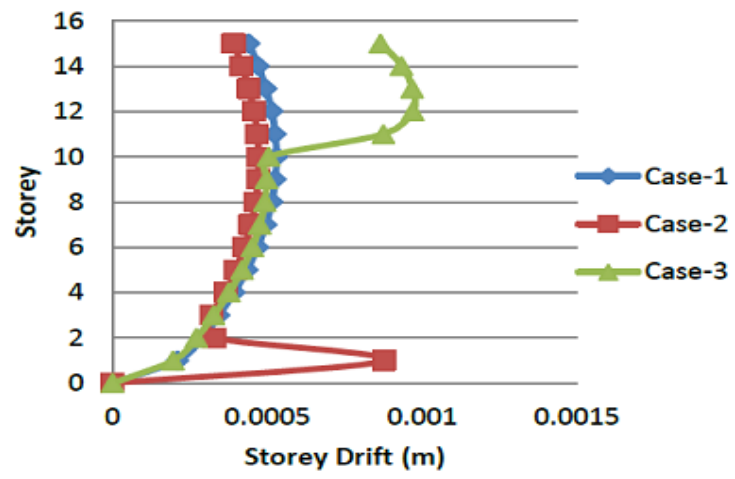

Figure 7: Story Drift in $\mathrm{x}$ direction

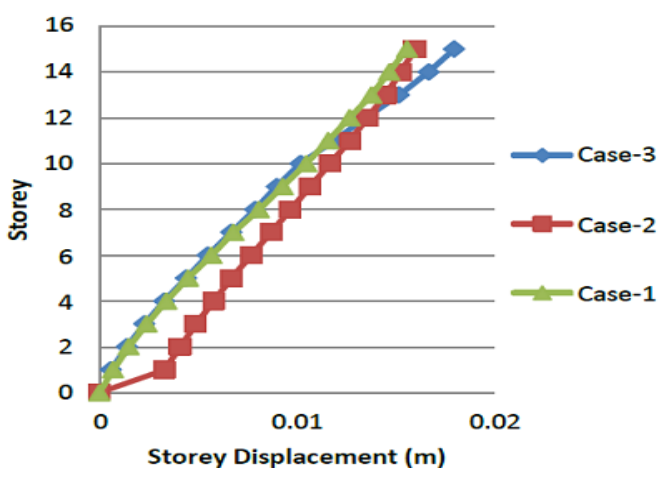

Figure 6: Story displacement in Y direction

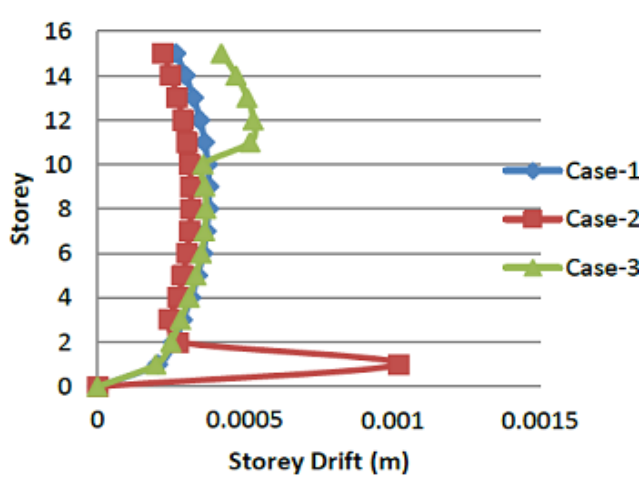

Figure. 8: Story Drift in Y direction 


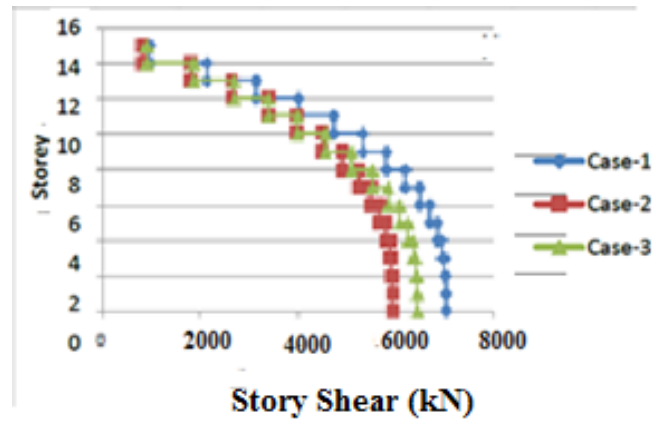

Figure 9: Story shear in $\mathrm{x}$ direction

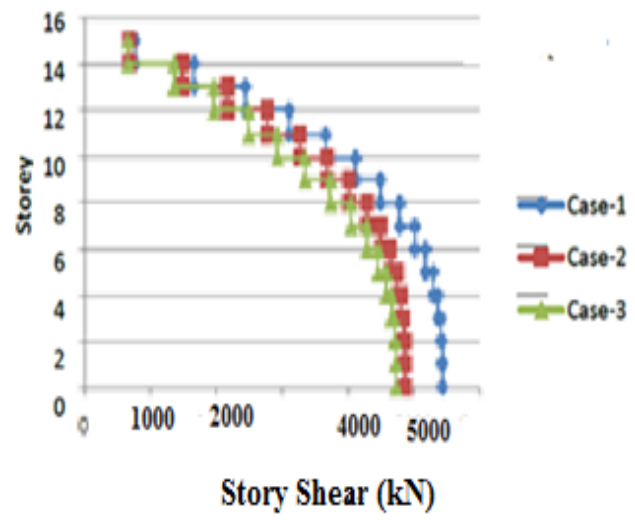

Figure 10: Story shear in Y direction

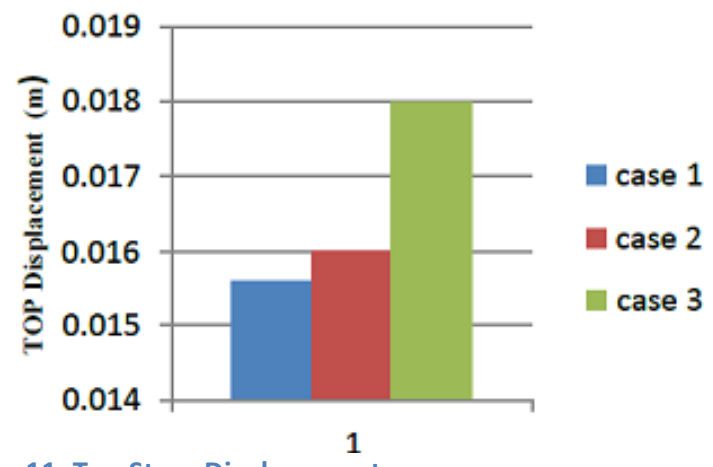

Figure 11: Top Story Displacement

\section{References}

[1] IS 1893:2002, "Indian Standard Criteria for Earthquake Resistant Design of Structures Part 1: General Provisions and Buildings", Fifth Revision.

[2] IS 875, "Indian Standard Code of Practice for Design Loads (Other than Earthquakes) For Building and Structures Part 2: Imposed Loads", Second Revision, Bureau of Indian Standards (BIS), New Delhi, 1987.

[3] S Monish \& S Karuna "Effect of Vertical Irregularity in RC Framed Buildings in Severe Seismic Zone" International Journal of Emerging Technology and Advanced Engineering, Volume 5, Issue 6, June 2015.

[4] Abul Hasnat \& M Rifat Ibtesham Rahim, "Response of Building Frames with Vertical and Stiffness Irregularity due to Lateral Loads" International Journal of Engineering Research \& Technology, Vol. 2 Issue 12, December - 2013.

[5] Hema Mukundan1 , S.Manivel, "Effect of Vertical Stiffness Irregularity on Multi-Storey Shear Wall framed Structures using Response Spectrum Analysis" , International Journal of Innovative Research in Science, Engineering and Technology, Vol. 4, Issue 3, March. 